\title{
Rancang Bangun Aplikasi Keamanan Brankas Berbasis Sinar Laser Dengan Mikrokontroller Arduino Nano Dan Uno R3
}

\author{
Donzilio Antonio \\ Program Studi Teknik Informatika STMIK Kupang \\ Jl. Adi Sucipto No. 12 A, Penfui \\ Kupang, NusaTenggara Timur \\ donziantonio@ymail.com
}

\begin{abstract}
Abstrak-Brankas merupakan salah satu target pencurian. Penulis memperkenalkan sebuah alat yang dapat mencegah dan paling tidak menghambat aksi kejahatan tersebut menggunakan sinar laser dibantu dengan Mikrokontroller Arduino Nano dan Uno R3. Keunggulan alat ini bisa mendeteksi benda asing menggunakan sensor cahaya dilengkapi dengan Buzzer dan Keypad, yang akan mengeluarkan suara atau bunyi jika ruangan tidak aman atau sedang disusupi oleh pihak yang tidak berwenang.
\end{abstract}

Keywords : Mikrokontroler Arduino Uno, Arduino Nano, Buzzer, Doorlock, Sinar Laser.

\section{PENDAHULUAN}

Keamanan menjadi salah satu faktor yang mempengaruhi kehidupan manusia, karena jika pada suatu lingkungan kurang aman maka hal tersebut sangat berpengaruh terhadap segala aspek kehidupan pada lingkungan tersebut. Keamanan terganggu oleh beberapa tindakan kejahatan diantaranya pencurian atau perampokan. Sehingga, beberapa orang maupun perusahaan berusaha untuk meminimalisir kejahatan tersebut. Salah satu upayanya adalah dengan menggunakan brankas. Menggunakan brankas dapat mengamankan beberapa benda yang berharga diantaranya perhiasan, uang maupun surat dan dokumen berharga pada sebuah perusahaan. Isi sebuah brankas tidak mudah diambil karena memerlukan autentikasi dari pemiliknya.

Tetapi walaupun sudah menggunakan brankas, tindakan kejahatan berupa pencurian tetap saja dapat terjadi. Seaman dan secanggih apapun, sebuah brankas sangat gampang dicuri jika pemiliknya tidak berada di tempat.

Berdasarkan masalah ini, penulis menawarkan sebuah solusi untuk mencegah pencurian brankas tersebut dan dapat dikontrol secara otomatis. Penulis mengembangkan sebuah alat keamanan berbasis sinar laser dibantu oleh microcontroller. Untuk membangun alat keamanan tersebut rumusan yang teridentifikasi adalah : a. Bagaimana mengkombinasikan microcontroller dengan sinar laser, keypad, door lock dan alarm yang dapat memberi sinyal tentang keamanan.

b. Bagaimana membuat respon atau memberikan sinyal pada orang yang menggunakan alat keamanan ini.

\section{METODE PENELITIAN}

Subjek dari penelitian ini adalah merancang bangun aplikasi keamanan brankas berbasis sinar laser. Literatur yang dijadikan acuan dan referensi dalam penelitian ini diambil dari berbagai sumber seperti buku, artikel dan jurnal ilmiah. Metode yang digunakan untuk pengembangan alat keamanan ini menggunakan metode berorientasi objek dengan memanfaatkan alat bantu berupa diagram Unified Modelling Language (UML). Diagram yang digunakan diantaranya Activity Diagram dan Deployment Diagram.

\section{PEMBAHASAN}

\section{A. Analisa Masalah}

Potensi tindak kejahatan yang dapat terjadi pada sebuah brankas adalah pada saat pemilik tidak berada ditempat dan tidak adanya alat untuk mendeteksi kejadian yang mungkin akan terjadi. Jika pun ada, alat pendeteksinya mempunyai respon yang lambat. Bentuk alat pendeteksi konvensionalnya pada umumnya hanya berupa alarm dengan sensor pada pintu. Konsepnya alarm akan mengeluarkan suara jika pintu di buka dengan paksa tanpa autentikasi. Namun, sistem ini mempunyai permasalahan yaitu dapat di non aktifkan dengan mudah. Sensor akan bekerja tetapi terlambat untuk diantisipasi. Sehingga dengan cara seperti ini kegunaan pendeteksi alarm tersebut sama saja tidak berfungsi. Model keamanan bentuk konvensional ini digambarkan pada diagram berikut. 


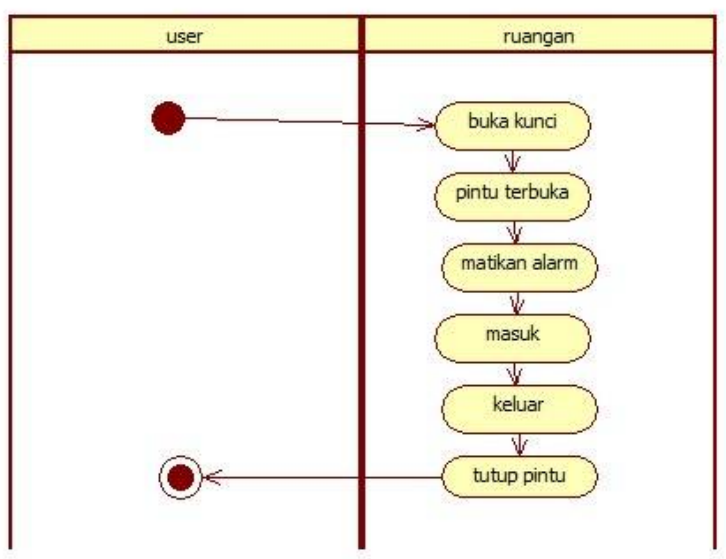

Gambar 1. Cara Kerja Sistem Keamanan Konvensional

\section{B. Perancangan Sistem}

Dalam merancang sistem keamanan brankas berbasis sinar laser ini terbagi menjadi dua bagian yaitu, perancangan perangkat keras (hardware) dan perancangan perangkat lunak (software).

Dalam sistem ini, user melakukan memasukkan pin pada keypad yang akan ditampilkan di $l c d$, kalau pintu tidak terbuka menandakan pin akan salah maka akan menimbulkan bunyi tertentu sebagai symbol kesalahan memasukkan pin pada tombol keypadnya, jika pin benar maka pintu akan terbuka dan alaram akan mati sekaligus dengan sinar lasernya juga akan mati dan yang terakhir lampu led merah akan mati, dan untuk menutup pintunya tekan tombol pagar pada keypadnya, maka secara otomatis pintu akan mengunci tersendiri, menyusul sinar laser menyala dan lampu led nya juga akan menyala sebagai simbol pintu sedang tertutup. Cara kerja dari rancangan alat pendeteksi keamanan brankas dapat dilihat pada diagram berikut.

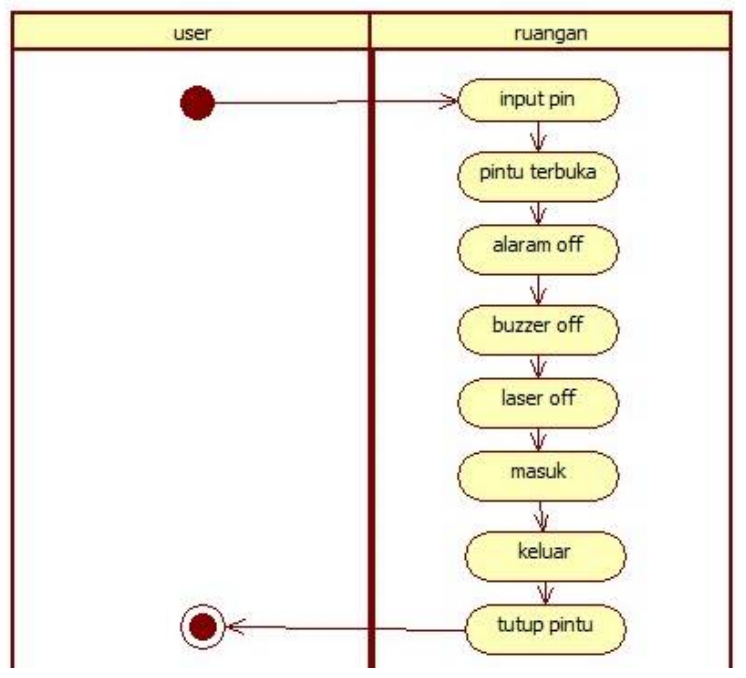

Gambar 2. Cara Kerja Sistem Keamanan yang diusulkan
Alat pendeteksi yang dirancang menggunakan mikrokontroller. Sehingga membutuhkan proses membuat membuat script program yang akan di upload ke mikrokontroller tersebut. Pembuatan script tidak langsung pada mikrokontrollernya, tetapi menggunakan PC melalui proses transfer data program dari PC ke mikrokontroller melalui kabel downloader. Mikrokontroller akan memproses data sesuai perintah script yang dibuat. Data atau perintah akan diteruskan keperangkat-perangkat mikrokontroller lainnya. Proses transfer data dapat dilihat gambar berikut.

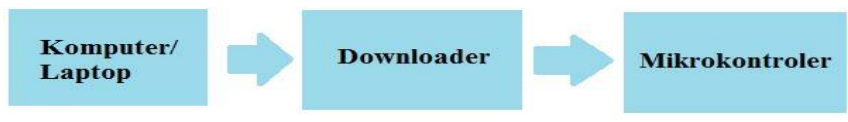

Gambar 3. Langkah Kerja Proses Download Data

Selain mikrokontroller, diperlukan juga beberapa perangkat keras yang lain untuk membentuk sebuah alat keamanan brankas menggunakan sinar laser. Beberapa perangkat keras yang dibutuhkan adalah keypad, relay, led, lcd, nano, sensor ldr dan laser. Hubungan setiap perangkat keras yang diperlukan dapat dilihat pada Deployment diagram berikut ini.

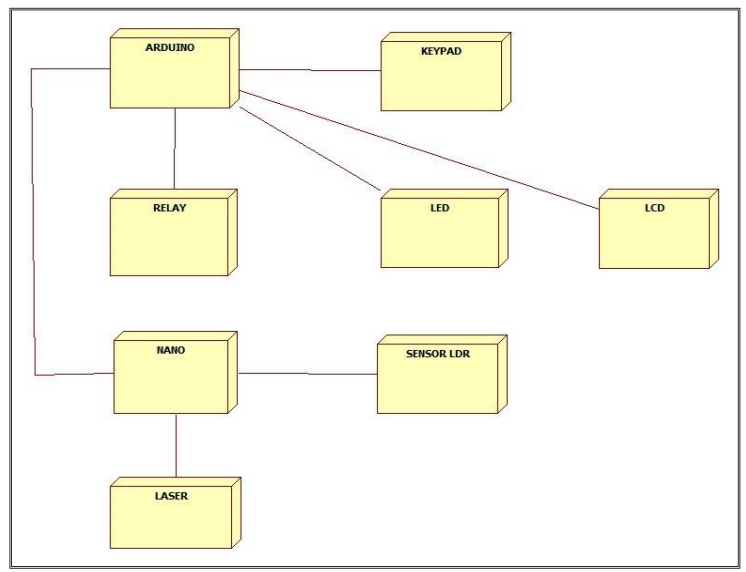

Gambar 4. Deployment Diagram

\section{Cara Kerja Sistem Keamanan Brankas}

Dari keterangan semua diatas maka penjelasan yang selanjutnya adalah menggabungkan seluruh flowchart dari awal sehingga menjadi kerangka kerja yang sebenarnya.

Proses dan cara kerja alat keamanan berkas adalah start kemudian dilanjutkan dengan inisialisai seluruh port,dari port laser,LDR,LCD,dan keypad, kemudian mengaktifkan LCD,dan relay akan aktif, setelah relay aktif maka laser akan mengeluarkan cahaya, nanti sinar cahaya ini akan di pantulkan ke LDR, dan LDR akan meneruskan ke arduino untuk diproses analisa, yang di analisa adalah" apakah cahaya kurang dari 
<700"? jika jawaban nya "iya" maka buzzer akan akan aktif dan disusul lampu led aktif.

Kemudian setelah $L D R$ berlanjut pada mengaktifkan keypad, langkah kerja pada keypad yaitu memasukkan pin atau password dan nantinya akan ditampilkan pada LCD, setelah menginput password maka akan segera di analisa " apakah password sudah benar"? jika password benar maka akan akan tampil hasil di layar lcd, dan laser akan non aktif dan doorlock segera terbuka dan jika password salah maka akan tampil “ acces denied" harus menginput kembali password denied" dan akan user harus menginput kembali password sampai benar.

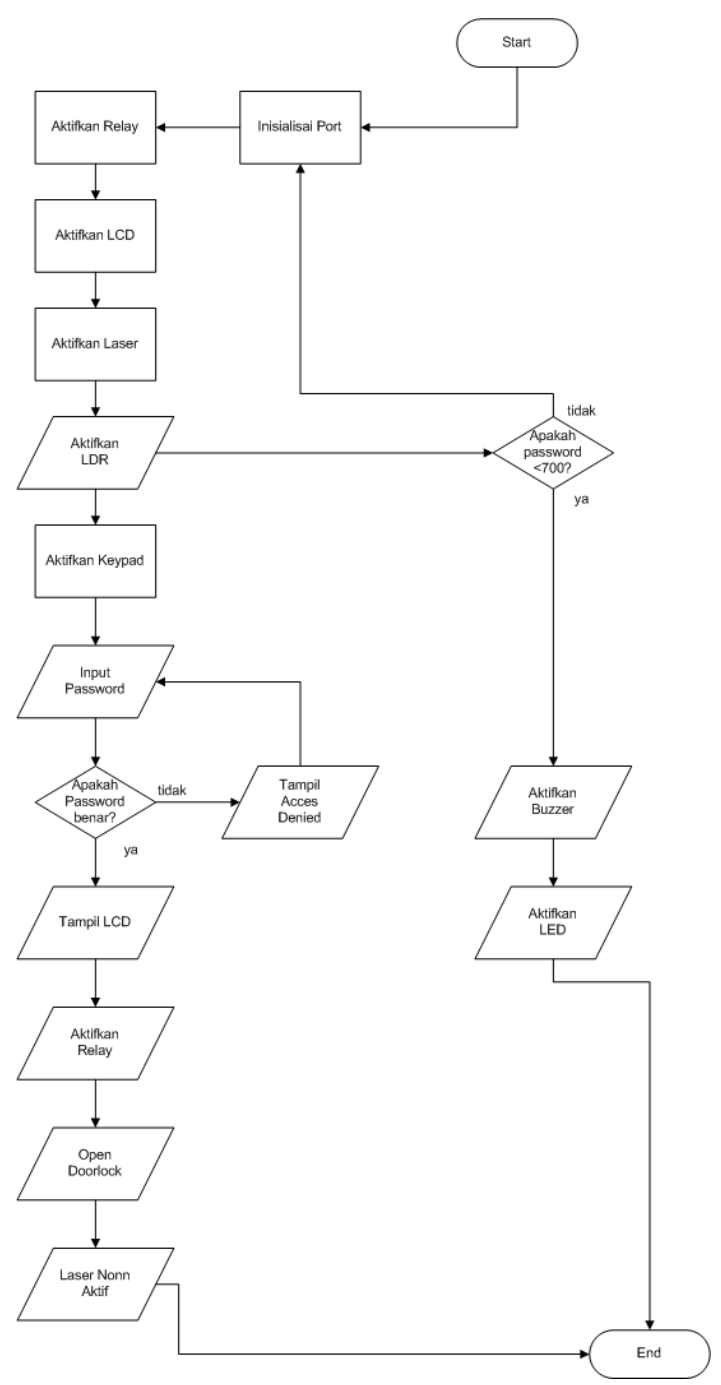

Gambar 5. Flowchart Cara Kerja Sistem Keamanan
Selain menggunakan flowchart untuk mengetahui proses dan cara kerja sistem keamanan brankas menggunakan sinar laser dapat dilihat pada alur pseudocode berikut ini.

1. Start

2. Inisialisasi port

3. Aktifkan relay

4. Aktifkan lcd

5. Aktifkan LASER

6. Aktifkan LDR

7. If cahaya <700 "tidak" Inisialisasi port "ya"

8. Aktifkan buzzer

9. Aktifkan LED"

10. Then

11. Aktifkan keypad

12. Input password

13. Apakah password sudah benar? " tidak" tampilkan acces denied "ya"

14. Tampilkan lcd "selamat datang Makruf"

15. Aktifkan relay

16. Open doorlock

17. Laser non aktif

Gambar 6. Pseudocode Cara Kerja Sistem Keamanan

D. Instalasi Rangkaian Keseluruhan

Rancang bangun di bawah ini merupakan rancangan instalasi keseluruhan yang di gabungkan menjadi satu sesuai kedudukan dan fungsi masing masing, yang semua rangkaian itu saling berhubungan.

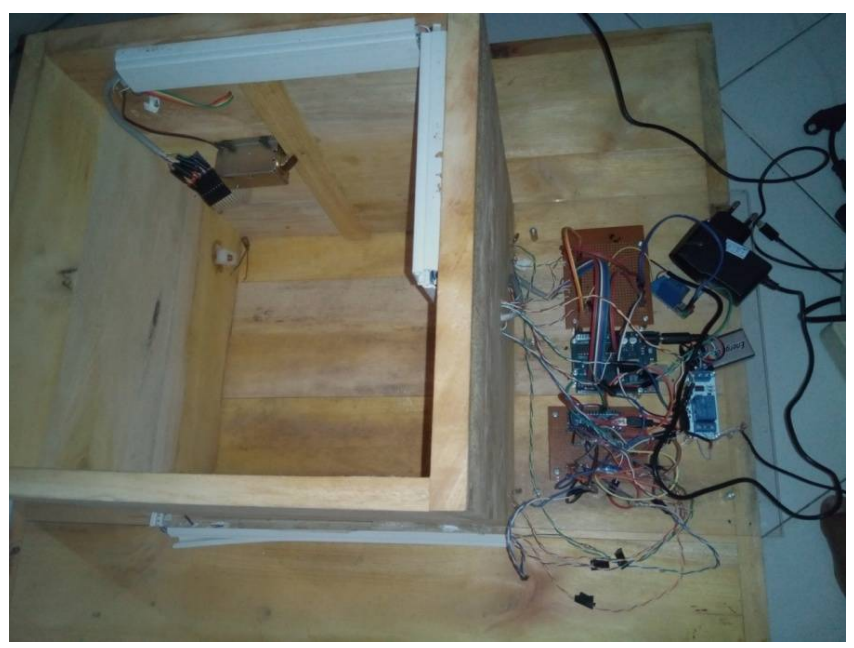

Gambar 7. Instalasi Rangkaian Keseluruhan 


\section{E. Instalasi Perangkat Lunak}

Instalasi perangkat lunak merupakan suatu proses instalasi software-software yang digunakan dalam membangun sistem rancang bangun alat keamanan rumah berbasis sinar laser. Proses instalasi yang ditunjukkan adalah instalasi duino IDE1.6.1 windows. Langkah pertama proses instalasi menampilkan pertanyaan persetujuan dari vendor.

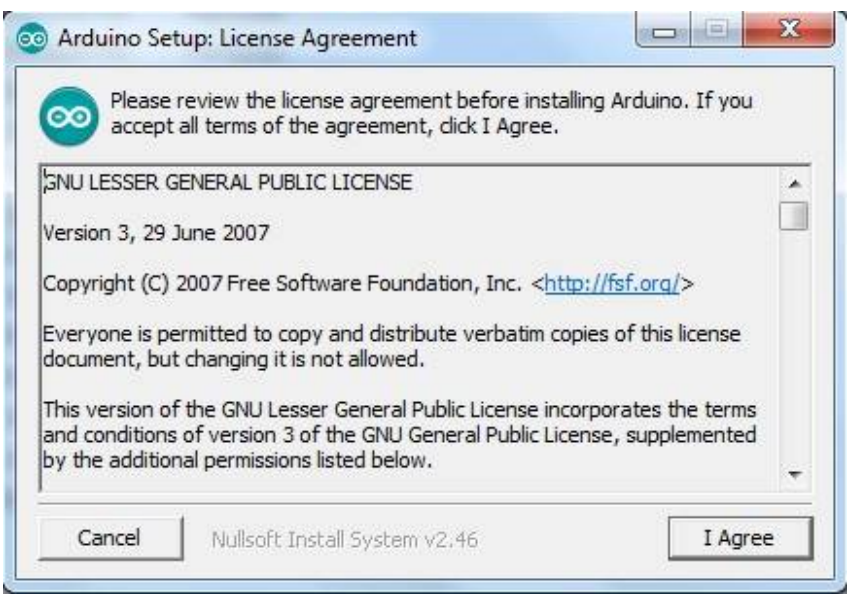

Gambar 8. Pernyataan Persetujuan Menggunakan Aplikasi

Proses berikutnya adalah proses memilih komponen yang akan diinstalasi. Pemilihan ini menentukan komponen yang akan digunakan.

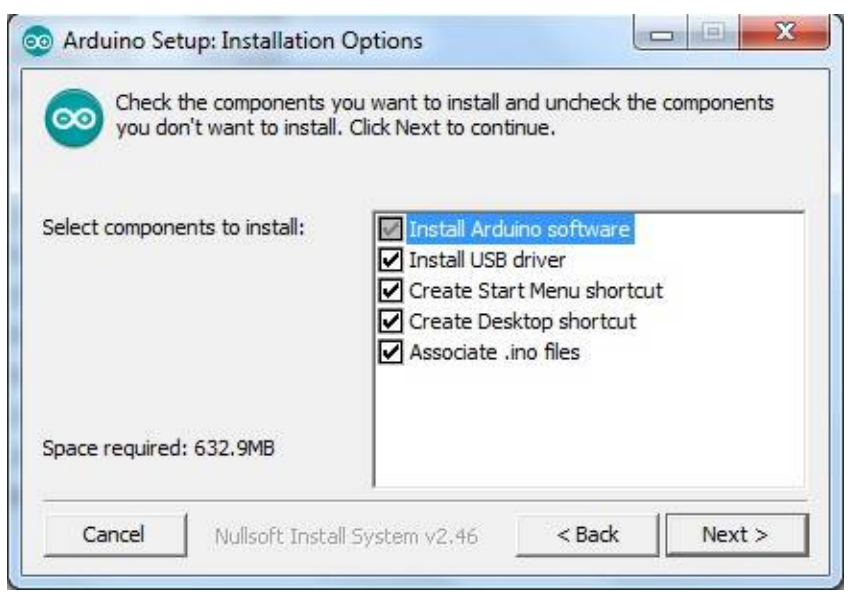

Gambar 9. Proses Pemilihan Komponen Untuk Instalasi
Proses berikutnya adalah proses pemilihan lokasi yang akan diinstalasi. Untuk memudahkan biasanya dipilih saja default lokasi yang akan diinstal.

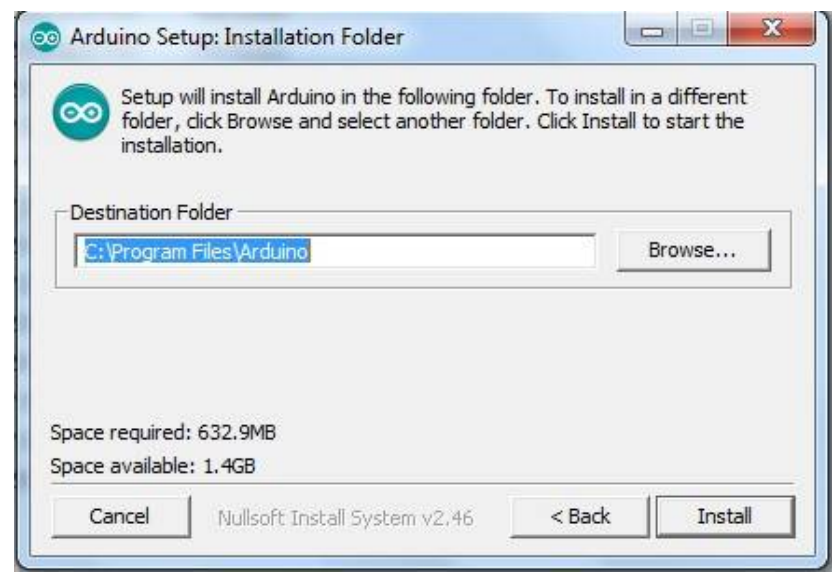

Gambar 10. Pemilihan Lokasi Instalasi

Selesai menentukan folder instalasi aplikasi, maka proses instalasi akan ditunjukkan pada windows.

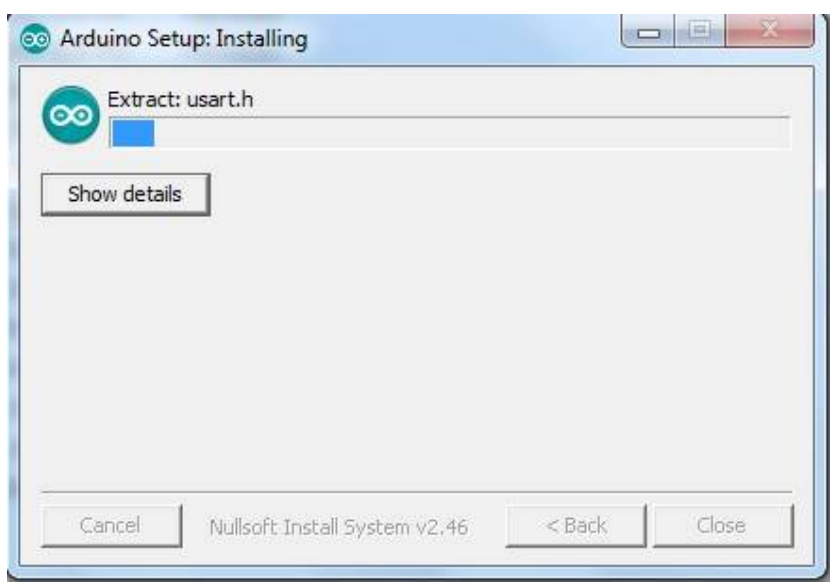

Gambar 11. Proses Instalasi

Proses instalasi dinyatakan selesai ditandai dengan tampilnya kotak dialog proses instalasi lengkap. 


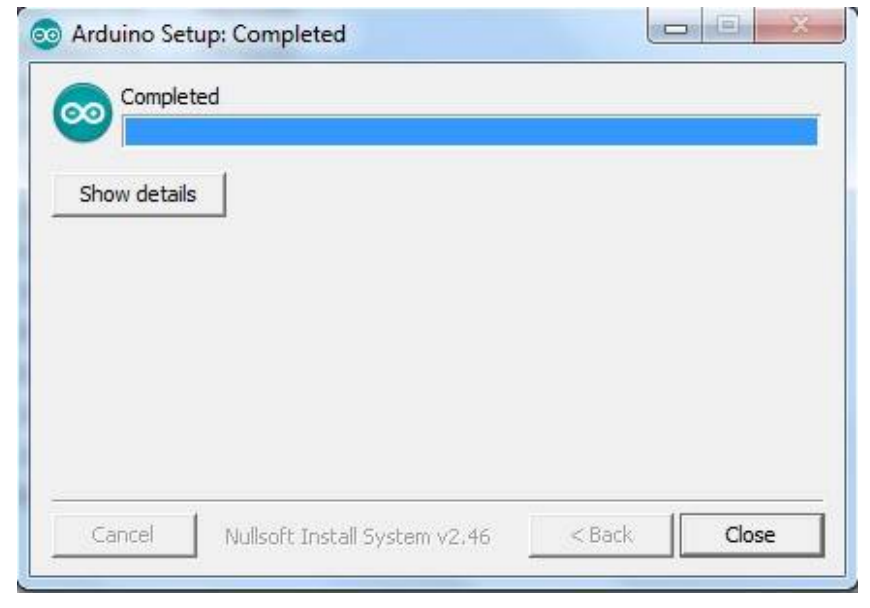

Gambar 12. Proses Instalasi Lengkap

\section{KESIMPULAN}

Berdasar hasil analisis, perancangan dan implementasi yang telah dilakukan, serta berdasarkan rumusan masalah yang ada, maka dapat diambil beberapa kesimpulan diantaranya sebagai berikut :

a. Alat Keamanan brankas berbasis sinar laser ini sangat efektif di perdesaan karena tidak memerlukan internet, sehingga sangat sesuai jika diterapkan di lingkungan yang mana jaringan internet nya kurang memadai.

b. Alat keamanan brankas berbasis sinar laser ini sangat aman karena di lengkapi dengan keypad yang mana keypad nya diatur memasuki password yang di peruntukkan bagi yang punya hak akses, sehingga hanya orang yang mempunyai hak akses yang bisa mengendalikan alat ini.

c. Alat keamanan brankas berbasis sinar laser tidak rentan error karena coding nya langsung di tanam pada mesin arduino secara langsung, sehingga tidak mudah error pada saat di aktifkan.

Alat keamanan brankas berbasis sinar laser ini sangat mempunyai sensor cahaya yang sangat sensitif dan jarak jangkau yang begitu jauh yang memungkin kan dapat mengoptimalkan keamanan lingkungan

\section{DAFTAR PUSTAKA}

[1] Purnama Rangsang. 2003. Tuntunan Pemrograman Java Jilid 2. Tim Prestasi Pustaka: Surabaya.

[2] Booch, G. James, R. Ivar, J, 2005. The Unified Modeling Language User Guide Second Edition. United State: Addison Wesley Professional.

[3] Cormen, Thomas H, Charles E. Leiserson, Ronald L. Rivest, and Clifford Stein. 2009.Introduction to Algorithms 3rd Ed. London. The MIT Press.

[4] Fowler, Martin.2005. UML Distilled. Edisi 3. Yogyakarta: Andi.

[5] Hartono, Bambang. 2013. Sistem Informasi Manajemen Berbasis Komputer. Jakarta: PT Rineka Cipta.

[6] Jogiyanto, Hartono, 2005. Analisis \& Desain Sistem Informasi Pendekatan Terstruktur Teori dan Praktek Aplikasi Bisnis. Andi Yogyakarta.

[7] Munawar. 2005. Pemodelan Visual dengan UML. Graha Ilmu: Yogyakarta.

[8] Nugroho,Adi. 2009. Rekayasa Perangkat Lunak Menggunakan UML Dan Java. ANDI, Yogyakarta.

[9] Nugroho,Adi. 2010. Rekayasa Perangkat Lunak Berbasis Objek dengan Metode USDP. Andi. Yogyakarta.

[10] Pressman, R.S. (2005). Software Engineering: A Practiotioner's Approach, Forth Edition, M cGraw-Hill Book, Co.

[11] Syahwil, Muhammad. Panduan Mudah Simulasi \& Praktek Mikrokontroler Arduino, Yogyakarta, 2013.

[12] Thomson, Jr., Arthur A.; Strickland III, A. J. 2001. Strategic Management Concepts and Cases. (12th Ed). McGraw-Hill Book Co., Singapore. 